\title{
Staging studies for evaluation of squamous cell carcinoma
}

\author{
Elaine S. Gould ${ }^{1} \cdot$ Kevin S. Baker $^{1} \cdot$ Ammar A. Chaudhry $^{1}$ • \\ Dinko Franceschi ${ }^{2} \cdot$ Syed Hoda $^{3}$
}

Question: Staging of left temporal squamous cell carcinoma Disclosures None. with positron emission tomography - computed tomography (PET-CT)

Figs. 1, 2, and 3

\section{Kevin S. Baker}

kevin.baker@stonybrookmedicine.edu

1 Stony Brook Medicine, Department of Radiology, HSC Level 4, Room 120, East Loop Road, Stony Brook, NY 11794, USA

2 Stony Brook Medicine, Department of Nuclear Medicine, HSC Level 4, Room 120 East Loop Road, Stony Brook, NY 11794, USA

3 Stony Brook Medicine, Department of Pathology, HSC Level 2 East Loop Road, Stony Brook, NY 11794, USA 
Fig. 1 AP abdominal radiograph (left) and coronal CT image of the abdomen/pelvis on bone window (right)

Fig. 2 Axial CT (upper left) on bone window, axial corrected PET (upper right), axial fused PET-CT on bone window (lower left), and coronal fused PET-CT on bone window (lower right)
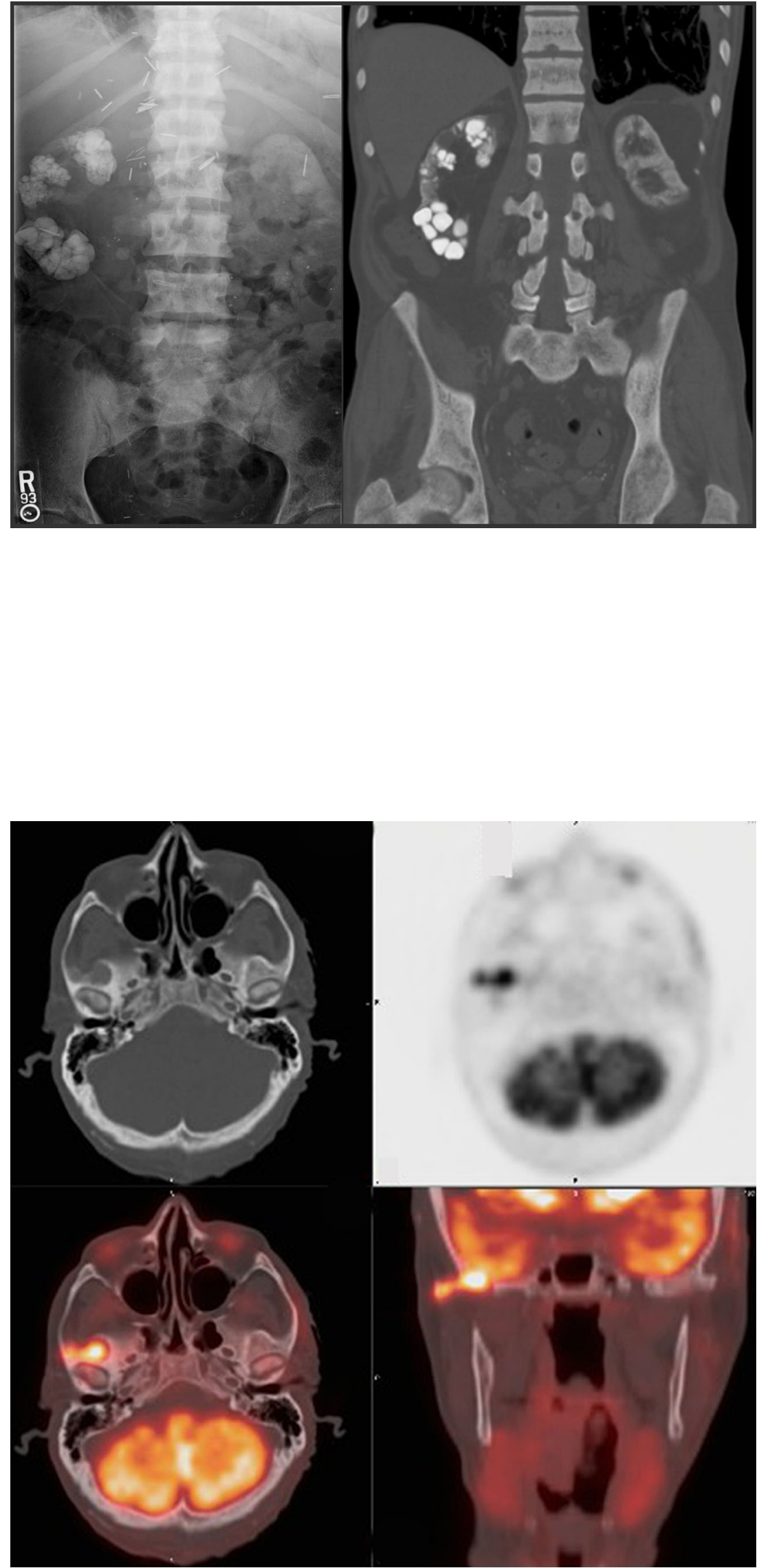
Fig. 3 Histopathologic images using hematoxylin and eosin (H \& E) stains at low power (20×, upper left), high power (40×, upper right), and high power polarized microscopy (40×, bottom)

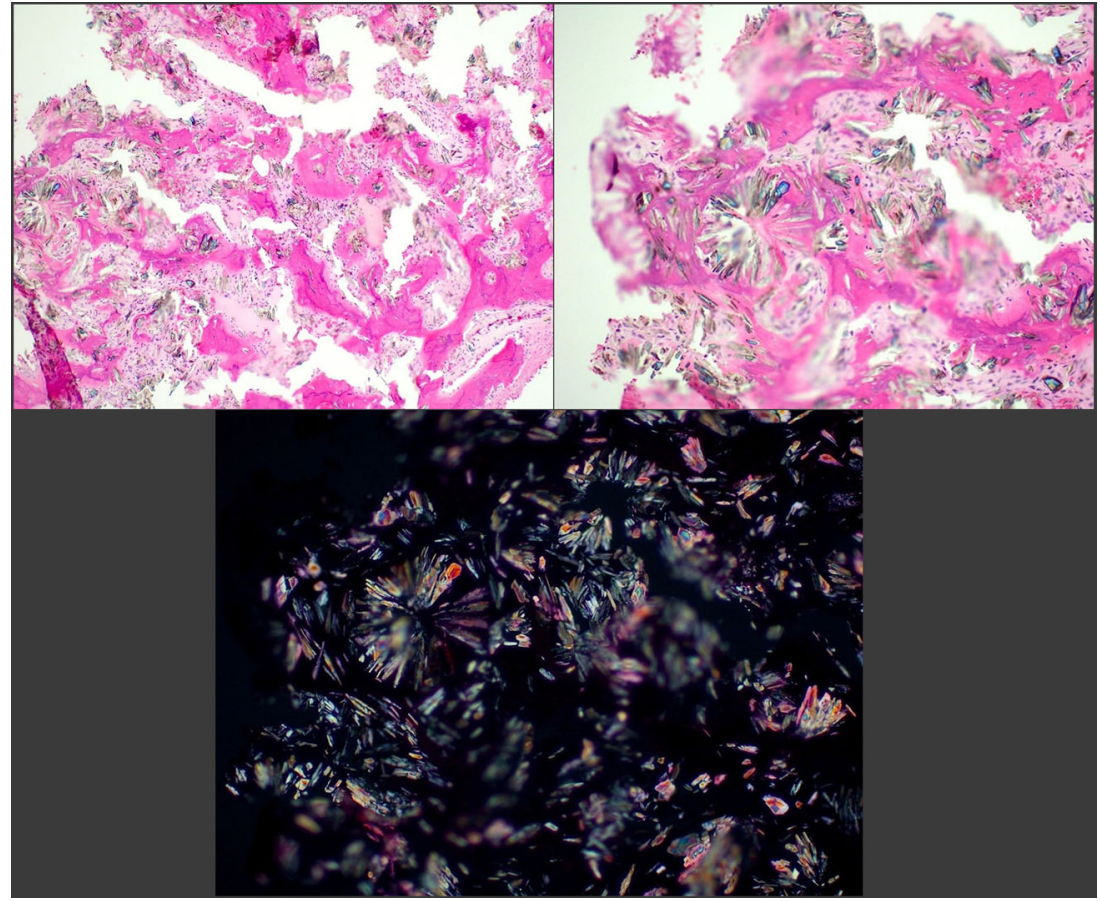

